Article

\title{
The Influence of Corn Straw Extrusion Pretreatment Parameters on Methane Fermentation Performance
}

\author{
Karol Kupryaniuk ${ }^{1}$, Tomasz Oniszczuk ${ }^{1, *}$ (D) Maciej Combrzyński ${ }^{1, *(\mathbb{D})}$, Wojciech Czekała ${ }^{2}$ (i) \\ and Arkadiusz Matwijczuk $3, *$ (D) \\ 1 Department of Thermal Technology and Food Process Engineering, University of Life Sciences in Lublin, \\ Głęboka 31, 20-612 Lublin, Poland; karol.kupryaniuk@o2.pl \\ 2 Institute of Biosystems Engineering, Poznań University of Life Sciences, Wojska Polskiego 50, \\ 60-627 Poznań, Poland; wojciech.czekala@up.poznan.pl \\ 3 Department of Physics, Lublin University of Life Sciences Akademicka 13, 20-950 Lublin, Poland \\ * Correspondence: tomasz.oniszczuk@up.lublin.pl (T.O.); maciej.combrzynski@up.lublin.pl (M.C.); \\ arkadiusz.matwijczuk@up.lublin.pl (A.M.)
}

Received: 26 May 2020; Accepted: 2 July 2020; Published: 6 July 2020

\begin{abstract}
The aim of the study is to determine the energy consumption of the extrusion-cooking process of corn straw under various conditions (screw speed, moisture content), water absorption measurements and water solubility indices as well as biogas efficiency evaluation. The extrusioncooking of corn straw was carried out using a single screw extruder with $\mathrm{L} / \mathrm{D}=16: 1$ at various rotational screw speeds $(70,90$, and $110 \mathrm{rpm})$ and with various initial moisture content of raw material (25 and 40\%). Prior to the process, the moisture content of the raw material was measured, and next, it was moistened to 25 and $40 \%$ of dry matter. For example, at $70 \mathrm{rpm}$ extruder screw speed, the temperature range was $126-150^{\circ} \mathrm{C}$. Energy consumption of straw pretreatment through extrusion-cooking was assessed in order to evaluate the possibility of using the process in an agricultural biogas plant. Biogas and methane efficiency of substrates after extrusion was tested in a laboratory scale biogas plant and expressed as a volume of cumulative methane production for fresh matter, dry matter, and dry organic matter. Pretreated corn straw moistened to $25 \%$ and processed at $110 \mathrm{rpm}$ during the extrusion-cooking processing produced the most advantageous effect for methane and biogas production (51.63\%) efficiency as compared to corn straw without pretreatment (49.57\%). Rotational speed of the extruder screw influenced biogas and methane production. With both dry matter and dry organic matter, the increase of rotational speed of the extruder screw improved the production of cumulated biogas and methane. Pretreatment of corn straw has a positive effect on the acquisition of cumulated methane $\left(226.3 \mathrm{Nm}^{3} \mathrm{Mg}^{-1}\right.$ for fresh matter, $243.99 \mathrm{Nm}^{3} \mathrm{Mg}^{-1}$ for dry matter, and $254.83 \mathrm{Nm}^{3} \mathrm{Mg}^{-1}$ for dry organic matter). Preliminary analysis of infrared spectra revealed changes in the samples also at the molecular level, thus opening up the possibility of identifying marker bands that account for specific degradation changes.
\end{abstract}

Keywords: corn straw; extrusion-cooking; pretreatment biogas production; renewable energy; FTIR spectra

\section{Introduction}

The most common substrates used in biogas plants are corn silage, slurry, and feedstocks in the form of lignocellulosic biomass. Triticale, maize/corn, rape straw, and hay also find application in such installations. Corn silage is one of the most widespread substrates of vegetable origin used for co-fermentation in agricultural biogas plants. In comparison to other cereal plants, it has a higher dry matter yield per hectare of crop, higher biogas yield, and lower cultivation costs. The methane 
fermentation process carried out in biogas plants helps dispose of waste substances that are seen as a burden to ecosystems. Waste from livestock production exhibits proper composition for the purpose of methane production. This is, for example, liquid manure, manure or droppings from poultry production. Much less desirable raw materials for biogas production are wastes with a high lignin content. Lignocellulosic biomass contains natural polymers such as cellulose, hemicellulose, and lignin [1-3]. Cellulose and hemicellulose as carbohydrates suitable as feedstock are fermentable after hydrolysis for bioenergy production. Unfortunately, lignocellulosic biomass is resistant to biodegradation by enzymes and microbes because of its inherent characteristics [4-6]. According to Eastman and Ferguson [7], the hydrolysis of sparingly soluble polymers, such as cellulose, lignins, and also decomposable fat, protein, and carbohydrate, is a limiting step in the rate of fermentation. They found that carbohydrates were more readily degraded than nitrogenous materials, and lipids remained unaffected. As shown by Di Matteo [8] scale becomes the crucial challenge to associate the feasible energy production due to application of cooking wastes in cities as effective substrate in biogas production. Energy balance is affected by the biogas production plant layout, especially by the choice of the digester technology. The whole chain calculations could be possible if industrial grade processes were tested as different equipments are needed for the treatment of food and agricultural wastes. Generally, any type of biomass can be used as a substrate for biogas production, provided it contains carbohydrates, proteins, fats, cellulose, and hemicellulose as the main components. Ultimately, this process must be preceded by earlier treatment that will disintegrate lignin, as well as releasing hemicellulose and cellulose. Pretreatment enhances the fermentation of substrates, which increases the efficiency of biogas production, including methane [9]. Scientific sources confirm that the use of pretreatment can improve the efficiency of biogas production to over $90 \%$ for raw materials such as grass, corn straw, and wood [6,10].

There are several methods of pretreatment of lignocellulosic biomass, among them chemical, biological, mechanical, and pressure-thermal treatment. Chemical treatment, useful in increasing methane efficiency, could be based on oxidation or treatment with peroxides, alkalis, and acids. In biological treatment methods, fungi, microbes, or enzymes are responsible for silage making. It is also worth mentioning that biological pretreatment methods are not only used for the production of silage itself but also microbes or enzymes can be added directly to the ready-made raw material. Disintegration of lignin, hemicellulose, and cellulose by mechanical methods include, i.e., radiation by ultrasound or microwaves, disintegration, extrusion, or steam explosion. All these methods are aimed to digest lignocellulosic substrates to increase biogas and methane efficiency during conversion to biogas by anaerobic digestion [6,11-13].

Extrusion-cooking is a pressure and thermal process that uses shear forces acting on processed material. The material undergoes heating and plasticization, so the mass can be shaped by a nozzle and expands [14-16]. The formation of shear forces and pressure is caused by the rotation speed of extruder screws. Single-screw and twin-screw extruders are used for the extrusion-cooking process. During the process, the extruder chamber has a high temperature reaching $200^{\circ} \mathrm{C}$, and various pressures can be obtained depending on the unit configuration. The process time during which biomass stays inside the extruder chamber depends on the length of the plasticizing system and the rotational speed of the extruder screw. During the processing of plant raw materials, lignin is broken in biomass; cellulose and hemicelluloses are also released and facilitate conversion [10,17].

Agricultural biogas plants based on the anaerobic digestion process implemented on a large scale around the world, use biomass obtained from plantations of energy plants as well as by-products and wastes of plant and animal origin. The NaWaRo biogas production system (NachWachsendeRohstoffe) mainly uses silage from plants (beet, corn, grass, etc.,). Other substrates, such as slurry, agricultural waste or grain, are also used depending on the specific circumstances of the processing farm. Substrates such as grass, bark, straw, and hay can also be used to produce biopolymers [18-20]. The processing of biogas by-products and waste products is important for environmental protection and generates energy. In economic terms, biogas plants are the most profitable. This statement is related to the fact 
that in Poland, subsidies available for electric energy production from agricultural biogas plants are the highest (over $170 \mathrm{EUR} / \mathrm{MWh}$ ), in fact over twice as high as in the case of photovoltaics and wind mills. Taking into account other possible profits from biogas plant exploitation (heat and digested sold, payment from problematic biowaste for treatment) it has to be assumed that in Polish conditions biogas plants can be the most profitable renewable energy installations.

The production of biogas through anaerobic digestion offers significant advantages over other forms of bioenergy production [21]. It has been evaluated as one of the most energy-efficient and environmentally beneficial technologies for bioenergy production [22]. The process of methane fermentation depends to a large extent on the conditions, availability, and type of the substrate. Depending on the raw material used, the mixture of gases produced as the final product will have different contents of methane, carbon dioxide, and other components. It is possible to use agricultural by-products: cereal straw, corn and cotton waste, plant stalks, animal residues (slurry, liquid manure, chicken poultry, litter), and others [23-25].

The aim of the study is to determine the stability of the extrusion-cooking process of lignocellulosic materials as well as performing the measurements of liquefaction of extrudates in water, the measurements of water absorption index and testing biogas efficiency. In addition, Fourier transform infrared spectroscopy (FTIR) was used to check selected samples for changes at the molecular level and attempt to identify marker bands of changes in the sample structures. The tests were carried out on plant extrudates produced at three rotational speeds of the extruder screw (70, 90 and $110 \mathrm{rpm})$ from raw material mixtures with the initial moisture of 25 and $40 \%$ of dry matter. It is noteworthy that the value the presented study stems from the evidence for the possibility of using straw-a cheap and readily available waste material generate in agricultural production, in the processes of extrusion and effective production of biogas ( 1 ton of straw can replace 3 tons of silage-a popular raw material used in biogas plants-while the prices of the two materials remain similar).

\section{Materials and Methods}

\subsection{Materials}

Corn straw used for research was harvested in 2017 and 2018 using a combine harvester and sifted to remove impurities. The straw was ground with a hammer shredder for a particle size of less than $10 \mathrm{~mm}$ and moistened to two moisture contents 25 and $40 \%$ by spraying with a suitable amount of water (extreme moisture levels at which the extrusion process can proceed without problems). Before processing, the materials were stored in sealed bags for a period of $24 \mathrm{~h}$ to unify the migration of water. The study pertained to maize straw whose chemical composition was derived from the most up-to-date source data $[26,27]$

\subsection{Processing}

The TS-45 (ZMChMetalchem, Gliwice, Poland) single-screw extruder with L/D = 16 and a $10 \mathrm{~kW}$ motor was used for the tests. The treatment processes were carried out in the temperature range $100-140{ }^{\circ} \mathrm{C}$ at three screw speeds of the 70,90 , and $110 \mathrm{rpm}$. The raw and treated materials are shown in Figure 1.

\subsection{Energy Consumption during Processing}

Energy consumption, expressed as SME [28] (specific mechanical energy), was calculated taking into account the engine load, the extruder-cooker working parameters, and the process efficiency of each test. The following formula was used:

$$
S M E=\frac{n}{n_{m}} \times \frac{O}{100} \times \frac{P}{Q}\left(\mathrm{kWh} \mathrm{kg}^{-1}\right)
$$


where: $S M E$-specific mechanical energy consumption $\left(\mathrm{kWh} \mathrm{kg}^{-1}\right), n$-screw rotation (rpm), $n_{m}$-screw rating rotation (rpm), $O$-engine load compared to maximum (\%), $P$-rated power $(\mathrm{kW})$, and $Q-$ process efficiency $\left(\mathrm{kg} \mathrm{h}^{-1}\right)$

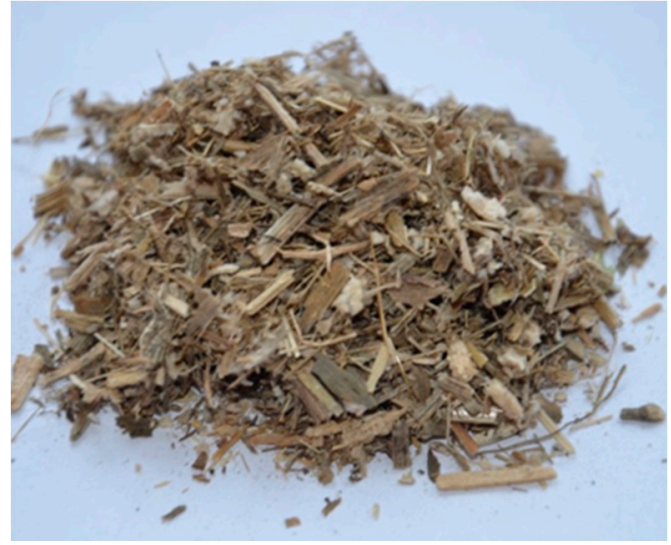

(a)

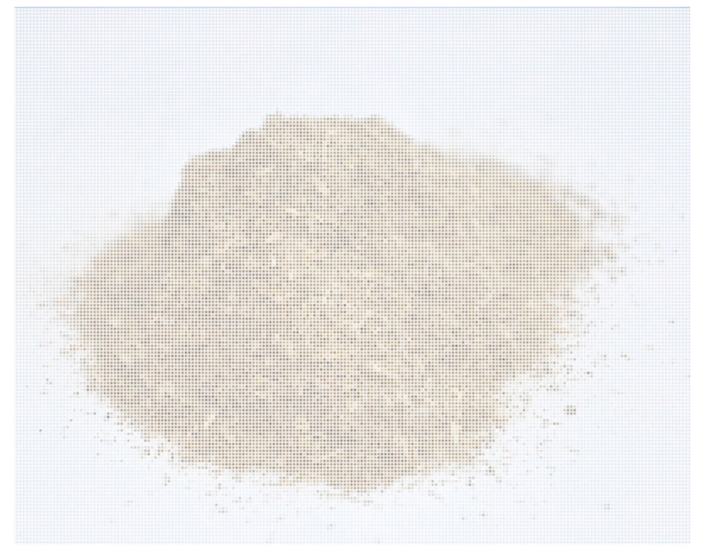

(b)

Figure 1. Raw (a) and extruded (b) corn straw used in the experiment.

\subsection{Water Absorption and Solubility Measurements}

The water absorption index (WAI) and the water solubility index (WSI) were used to evaluate the cooking intensity by extrusion according to the method described by Bouasla et al. [29]. For this purpose, $7 \mathrm{~mL}$ of distilled water was added to $0.7 \mathrm{~g}$ of the extruded sample. The sample was mixed and put aside for $10 \mathrm{~min}$, then centrifuged for $10 \mathrm{~min}$ at 15,000 rpm. The centrifuged samples were filtered, and the remains after gel formation were dried in an air oven at $105^{\circ} \mathrm{C}$ until they were completely dry. The WAI was calculated as the mass of sludge per constant dry weight of the sample, and the WSI was calculated as the amount of residue dissolved in the supernatant. All measurements were made in triplicate.

\subsection{Biogas Efficiency Analysis}

The samples of extruded corn straw were analyzed for biogas efficiency using standard methods (DIN 38414/S8 and VDI 4630). Biogas production was carried out in a multi-chamber biofermentors at the Ecotechnologies Laboratory of the Institute of Biosystems Engineering, Poznań University of Life Sciences (Scheme 1) [30,31]. Fermentation reactors with a capacity of $2 \mathrm{dm}^{3}$ were filled with inoculum (separated liquid fraction of digestate from real scale agricultural biogas) and extruded corn straw processed under different conditions. The percentage of dry matter in the inoculum should be between 1.5 and $2 \%$. Before the experiment, the dry matter and the organic dry matter were measured, and the substrates were placed in an airtight fermentation reactor. The sample chambers were placed in temperature-controlled water (around $39^{\circ} \mathrm{C}$ ) which simulated the mesophilic conditions of the biogas plant. Biogas produced in each separate chamber was transferred to storage tanks filled with neutral liquid. The volume of produced biogas was measured every $24 \mathrm{~h}$ until the daily production of biogas was lower than $1 \%$ of the total volume of biogas produced. The test was performed in three replications. The biogas efficiency of the substrate $\left(\mathrm{Nm}^{3} \mathrm{Mg}^{-1}\right.$ organic dry matter) was calculated based on experimental results, as described by Dach et al. [30]. The normal volume of methane was calculated by multiplying the normal volume of dry gas by the methane content in dry gas and expressed as accumulated methane and combined biogas on dry matter and dry organic matter of corn straw.

\subsection{Infrared Spectra Measurements}

Measurements of infrared spectra for the analyzed samples were conducted with the use of a 670-IR spectrometer (Agilent, Santa Clara, CA, USA). An ATR (attenuated total reflection) attachment 
was used in the form of a ZnSe crystal with adequate geometry (truncated at $45^{\circ}$ ) to ensure 20 -fold internal reflection of the absorbed beam. During the measurement, 24 scans were registered, and, subsequently, the programme averaged the results for all spectra. Prior to the measurement, the ZnSe crystal was cleaned using ultra-clear solvents by Sigma-Aldrich (Sigma-Aldrich, St. Louis, MO, USA). Prior to $(1 \mathrm{~h})$ and during the experiment, the measurement chamber was kept in an inert $\mathrm{N}_{2}$ atmosphere. Spectral measurements were recorded in the region from 550 to $3800 \mathrm{~cm}^{-1}$ at the resolution of $0.5 \mathrm{~cm}^{-1}$. The measurements were conducted at the Department of Biophysics Laboratory of the University of Life Sciences in Lublin. The spectra were analyzed and processed with the use of the Grams/AI software (version Suite 9.3) by ThermoGalactic Industries (Waltham, MA, USA). The spectra were normalized at the wave number of $1025 \mathrm{~cm}^{-1}$ (for easier analysis). All the spectra were measured at room temperature.

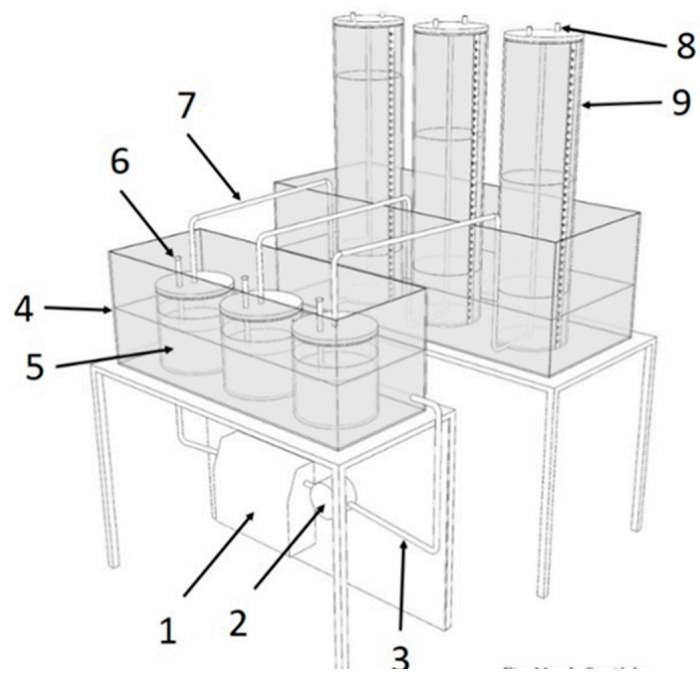

Scheme 1. A design of biofermentor for biogas production research (3-chamber section): 1-water heater with temperature regulator, 2-water pump, 3-insulated conductors of calefaction liquid, 4-water coat, 5-biofermentor with the charge capacity of $2 \mathrm{dm}^{3}, 6$-sampling tubes, 7-biogas transporting tube, 8-gas sampling valve, 9-biogas volume-scale reservoir [31].

\subsection{Statistical Analysis}

The obtained results from three test replicates were subjected to a statistical analysis using Statistica 13.3 software (StatSoft,13.3, Cracow, Poland). Regression equations of quadratic models, correlation coefficients, and statistical one-way analysis of variance (ANOVA) with F-test and Kruskal-Wallis test were used to analyze the results at $\alpha=0.05$. The results were found as significantly affected by the screw speed at different moisture content as $p$ value was lower than 0.05 . Results are presented as mean value with \pm standard deviation.

\section{Results and Discussions}

\subsection{Effect of Processing Conditions on Extrusion Energy Consumption}

Pretreatment of corn straw by extrusion-cooking was carried out using a single-screw extruder type TS-45. The energy consumption during corn processing ranged from 0.206 to $0.332 \mathrm{kWh} \mathrm{kg}^{-1}$ at $70 \mathrm{rpm}$, from 0.202 to $0.301 \mathrm{kWh} \mathrm{kg}^{-1}$ at $90 \mathrm{rpm}$ and from 0.198 to $0.269 \mathrm{kWh} \mathrm{kg}^{-1}$ at $110 \mathrm{rpm}$, as shown in Figure 2a. The moisture content increased from $25 \%$ to $40 \%$ reduces energy consumption, regardless of the rotational speed used during processing. Pre-processed samples of corn straw moistened to $40 \%$ were characterized by the lowest energy requirements during processing at $110 \mathrm{rpm}$, while samples processed at $25 \%$ of moisture content and $70 \mathrm{rpm}$ were characterized by the highest energy demand. Water can act as a lubricant and reduce energy requirements, but it can also affect the mechanical 
behavior of materials obtained during extrusion cooking [32]. The increase in rotational speed of the extruder screw has an impact on the change of SD. A significant effect $(p<0.05)$ of screw speed on energy consumption was observed for the initial moisture content of both raw materials at the high values of correlation coefficients, which suggests a decrease in energy consumption along with a higher screw speed during processing (Table 1). A more intense effect was noted when $25 \%$ of moisture was used (higher values of F-test). These conditions generate the least energy demand during pretreatment, so it can be recommended as a pretreatment method useful for increasing biogas efficiency with low energy expenditure. Menardo et al. [33] used a counter-rotating twin-screw extruder driven by a $74 \mathrm{~kW}$ motor for the treatment of biomass containing rice straw silage, maize silage, and triticale silage. They reported that an increase in obtained energy for feeds containing $10 \%$ of rice straw was higher than the energy needed for extrusion, but the energy balance was close to zero when $30 \%$ of rice straw was used.

a)
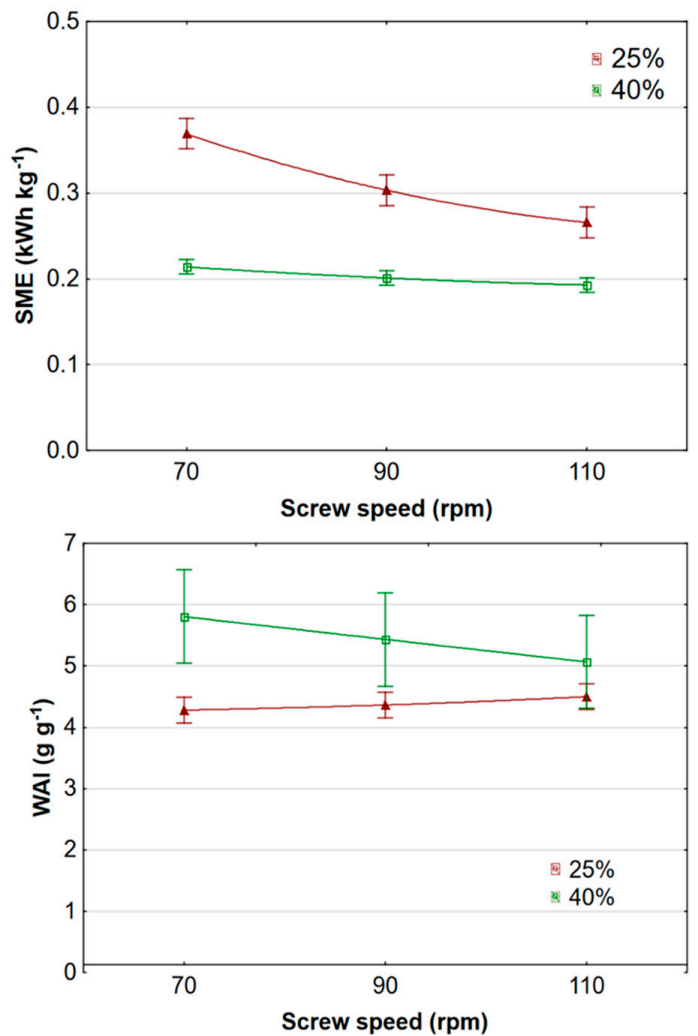

b)

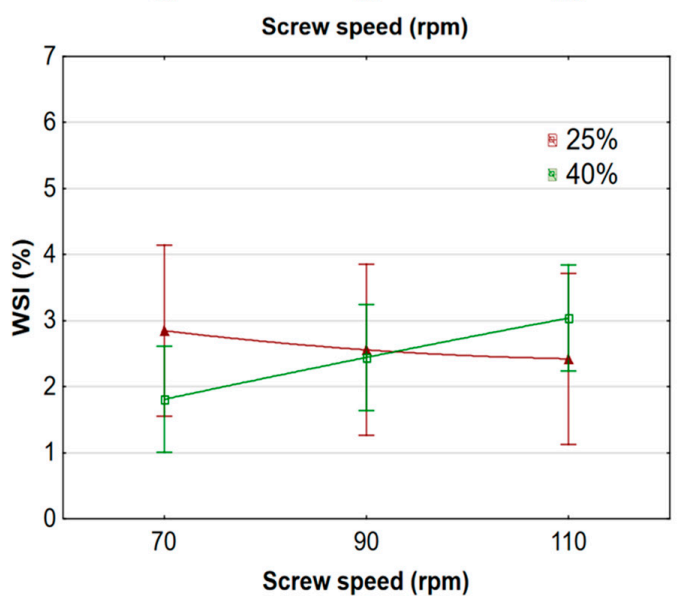

Figure 2. Selected properties of corn straw extruded under various screw speeds and moisture content: (a) energy consumption, (b) water absorption index, (c) water solubility index. 
Table 1. Regression equations, correlation coefficients and statistical one-way analysis of variance (ANOVA) with F-test and Kruskal-Wallis test depend on screw speed used during pretreatment of corn straw.

\begin{tabular}{|c|c|c|c|c|c|c|c|}
\hline Variable & $\begin{array}{c}\text { Moisture } \\
\text { Content }(\%)\end{array}$ & Equation & $\begin{array}{l}\text { Correlation } \\
\text { Coefficient }\end{array}$ & F-Test & $p$ Value & $\begin{array}{c}\text { Kruskal-Wallis } \\
\text { Test }\end{array}$ & $p$ Value \\
\hline \multirow{2}{*}{$\begin{array}{c}\text { SME } \\
\left(\mathrm{kWh} \mathrm{kg}^{-1}\right)\end{array}$} & 25 & $0.463-0.108 x+0.014 x^{2}$ & -0.974 & 105.315 & $0.00002 *$ & 7.200 & $0.0273 *$ \\
\hline & 40 & $0.232-0.021 x+0.003 x^{2}$ & -0.919 & 18.611 & $0.0027 *$ & 7.200 & 0.0273 * \\
\hline \multirow{2}{*}{$\begin{array}{l}\text { WAI } \\
\left(\mathrm{g} \mathrm{g}^{-1}\right)\end{array}$} & 25 & $4.243+0.012 x+0.024 x^{2}$ & 0.717 & 3.282 & 0.1089 & 3.518 & 0.1722 \\
\hline & 40 & $6.181-0.379 x+0.003 x^{2}$ & -0.696 & 2.823 & 0.1367 & 5.535 & 0.0628 \\
\hline \multirow{2}{*}{$\begin{array}{l}\text { WSI } \\
(\%)\end{array}$} & 25 & $3.295-0.524 x+0.078 x^{2}$ & -0.312 & 0.339 & 0.7253 & 1.412 & 0.4937 \\
\hline & 40 & $1.134+0.694 x-0.019 x^{2}$ & 0.838 & 7.055 & $0.0266^{*}$ & 6.489 & 0.0390 * \\
\hline \multirow{2}{*}{$\begin{array}{l}\text { Methane content } \\
(\%)\end{array}$} & 25 & $51.24+0.145 x-0.005 x^{2}$ & 0.982 & 82.765 & $0.00004 *$ & 7.200 & 0.0273 * \\
\hline & 40 & $52.47-1.282 x+0.182 x^{2}$ & -0.715 & 3.381 & 0.1039 & 4.622 & 0.0992 \\
\hline \multirow{2}{*}{$\begin{array}{l}\text { Cumulative methane } \\
\left(\mathrm{Nm}^{3} \mathrm{Mg}^{-1} \text { f.m.) }\right.\end{array}$} & 25 & $221.66+3.082 x-0.512 x^{2}$ & 0.816 & 7.687 & $0.0221 *$ & 6.879 & 0.0321 * \\
\hline & 40 & $222.6-2.487 x-0.113 x^{2}$ & -0.952 & 28.984 & $0.0008 *$ & 7.200 & 0.2730 \\
\hline \multirow{2}{*}{$\begin{array}{l}\text { Cumulative biogas } \\
\left(\mathrm{Nm}^{3} \mathrm{Mg}^{-1} \text { f.m.) }\right.\end{array}$} & 25 & $437.21-0.138 x+0.202 x^{2}$ & 0.924 & 21.939 & $0.0017^{*}$ & 6.879 & 0.0321 * \\
\hline & 40 & $429.54-1.52 x+0.067 x^{2}$ & -0.940 & 22.785 & $0.0016^{*}$ & 7.2605 & 0.0265 * \\
\hline \multirow{2}{*}{$\begin{array}{l}\text { Cumulative methane } \\
\left(\mathrm{Nm}^{3} \mathrm{Mg}^{-1} \text { d.m. }\right)\end{array}$} & 25 & $237.81+2.755 x-0.208 x^{2}$ & 0.970 & 51.939 & $0.0002 *$ & 7.200 & 0.2730 \\
\hline & 40 & $240.74-0.583 x+0.35 x^{2}$ & 0.895 & 17.006 & $0.0034^{*}$ & 6.252 & 0.0439 * \\
\hline \multirow{2}{*}{$\begin{array}{l}\text { Cumulative biogas } \\
\left(\mathrm{Nm}^{3} \mathrm{Mg}^{-1} \text { d.m. }\right)\end{array}$} & 25 & $448.33+27.082-8.005 x^{2}$ & -0.296 & 0.588 & 0.5843 & 2.400 & 0.3012 \\
\hline & 40 & $461.07+7.892 x-0.332 x^{2}$ & 0.984 & 91.690 & $0.00003 *$ & 7.200 & 0.2730 \\
\hline \multirow{2}{*}{$\begin{array}{l}\text { Cumulative methane } \\
\left(\mathrm{Nm}^{3} \mathrm{Mg}^{-1} \text { d.o.m. }\right)\end{array}$} & 25 & $248.59+2.77 x-0.237 x^{2}$ & 0.924 & 18.196 & $0.0028 *$ & 7.200 & 0.0273 * \\
\hline & 40 & $251.84+0.352 x-0.068 x^{2}$ & 0.383 & 0.675 & 0.5439 & 1.367 & 0.5049 \\
\hline \multirow{2}{*}{$\begin{array}{l}\text { Cumulative biogas } \\
\text { ( } \mathrm{Nm}^{3} \mathrm{Mg}^{-1} \text { d.o.m.) }\end{array}$} & 25 & $485.31+4.258 x-0.468 x^{2}$ & 0.933 & 22.458 & 0.0016 * & 7.200 & 0.0273 * \\
\hline & 40 & $484.95+5.53 x-0.023 x^{2}$ & 0.970 & 47.510 & $0.0002 *$ & 7.200 & 0.0273 * \\
\hline
\end{tabular}

\subsection{WAI and WSI of Extruded Corn Straw}

The extruded corn straw was tested for the WAI and WSI, where the WAI reflects the amount of water bound by the product while the WSI represents the amount of small molecules dissolved in water depending on molecular damages caused by processing conditions [27,32]. The WAI and WSI results for extruded corn straw are shown in Figure $2 b$,c. For a moisture content of $25 \%$, it was observed that the WAI increased with a higher screw rotational speed (Figure 2b). An opposite relationship was observed for the extruded corn straw with a moisture content of $40 \%$. The increase in rotational speed of the extruder caused a gradual decrease in the value of WAI.

Water-soluble components also vary depending on the processing conditions. Small differences were observed for the WSI of corn straw extruded at $25 \%$ of moisture content regardless of the screw speed during processing (Figure 2c). For samples with the initial humidity of $40 \%$, differences in the WSI were more significant. The highest WAI $\left(5.80 \mathrm{~g} \mathrm{~g}^{-1}\right)$ and the lowest WSI $(1.81 \%)$ were recorded for samples processed at $40 \%$ humidity and $70 \mathrm{rpm}$. For the $25 \%$ moisture tests, the lowest WAI $\left(4.28 \mathrm{~g} \mathrm{~g}^{-1}\right)$ and the highest WSI $(2.85 \%)$ were recorded for samples processed at $70 \mathrm{rpm}$. A significant effect $(p<0.05)$ of screw speed on the WSI was observed for $40 \%$ of initial moisture content of corn straw (Table 1). This was likely connected with the thermal and mechanical treatment during the extrusion-cooking of lignocellulose biomass, causing a larger active area as the processed material expanded by the pressure difference inside and outside of extruder barrel, and probably partial hydrolysis of cellulose components due to heating [10].

\subsection{Biogas Efficiency}

The use of extrusion for pretreatment of corn straw used as a source of biomass affected significantly higher methane content (51.63\% for pre-treated straw) after anaerobic fermentation compared to the control sample (49.57\% for corn straw without pretreatment). Only the maximum methane efficiency, the substrate and the specific reaction rate must be known from a continuously digestion test [21,34-36]. The results regarding the methane content, as shown on Figure 3, indicated lower methane efficiency if 
corn straw was pretreated at $40 \%$ of initial moisture content. A significant effect $(p<0.05)$ of screw speed on methane content was observed if initial moisture content was of $25 \%$ with a high value of correlation coefficient (Table 1). Gizińska-Górna et al. [37] demonstrate that the content of methane in biogas ranged from 50.9 to $54.9 \%$ if common reed and Jerusalem artichoke were used for fermentation, and these values were rather lower compared to other typical substrates for biogas production. Pilarski et al. [10] found that pretreatment by extrusion was useful in improving the quantity of generated methane: as regards fresh matter for maize silage subjected to extrusion, the methane yield was $16.48 \%$ higher than that of the non-extruded silage. Application of a short single-screw extruder with L/D ratio of the screw of $6: 1$ and rotational speed of $200 \mathrm{rpm}$ showed that maize straw silage after extrusion gave $35.30 \%$ more methane at mesophilic digestion than non-extruded material. Menardo et al. [33], using twin-screw extrusion of rice straw mixed with maize silage and triticale silage, reported an increase in the methane yield by $15.7 \%$ because organic matter degradation was started.

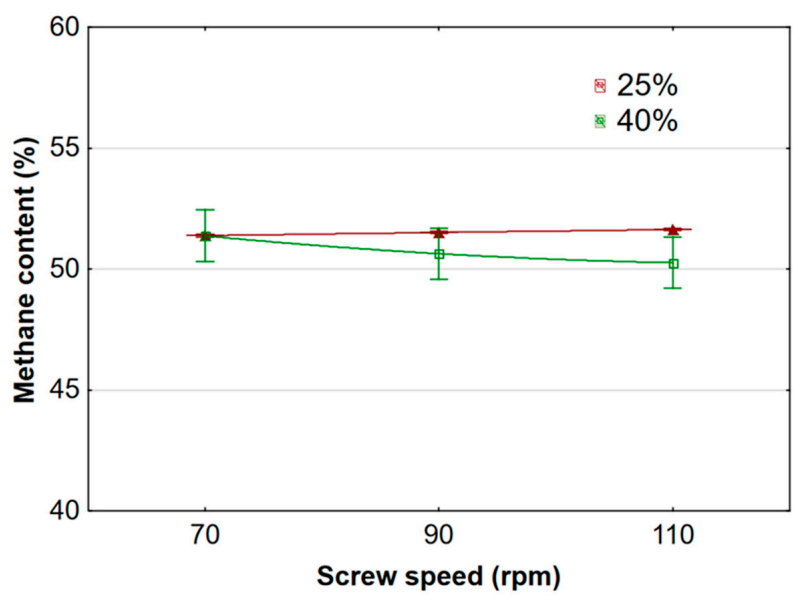

Figure 3. Methane content in produced biogas after fermentation of corn straw pretreated in various extrusion-cooking conditions.

In all tested samples, cumulative methane treated with extrusion-cooking was higher than in the control corn straw, and the formation of accumulated methane was more intensive, both for fresh and dry matter (Figure 4). The amount of cumulative methane production during fermentation of untreated corn straw was lower; the corresponding values were $197.34 \mathrm{Nm}^{3} \mathrm{Mg}^{-1}$ for fresh matter, $219.35 \mathrm{Nm}^{3} \mathrm{Mg}^{-1}$ for dry matter, and $228.78 \mathrm{Nm}^{3} \mathrm{Mg}^{-1}$ for dry organic matter. Extrusion-cooking pretreatment of corn straw allowed the achievement of more efficient methane efficiency with an increase of $8-15 \%$ for fresh matter, $9-11 \%$ for dry matter, and $10-11 \%$ for dry organic matter, respectively compared to untreated corn straw. Higher values of cumulative methane were obtained for dry organic matter for both moisture levels used in the experiment compared to other efficiency calculations. The highest value $\left(254.83 \mathrm{Nm}^{3} \mathrm{Mg}^{-1}\right)$ was observed for dry organic matter for samples extruded at $25 \%$ of the initial moisture of straw and screw speed of $110 \mathrm{rpm}$ (Figure $4 \mathrm{c})$. The lowest value $\left(214.06 \mathrm{Nm}^{3} \mathrm{Mg}^{-1}\right)$ was observed for the cumulative amount of methane in fresh matter when the samples used were extruded at $40 \%$ of the initial moisture of corn straw and at the screw speed of $110 \mathrm{rpm}$ during processing. Higher screw speed applied for corn straw pretreatment enhanced methane efficiency, except for fresh matter calculated when $40 \%$ of initial moisture content applied during extrusion-cooking (Figure $4 \mathrm{a}$ ). Only in the case of moisture, a $40 \%$ increase in the initial moisture content caused a decrease in methane efficiency. Gizińska-Górna et al. [37] reported that methane production during anaerobic digestion was the highest from common reed (108 $\mathrm{Nm}^{3} \mathrm{Mg}^{-1}$ f.m. and $212.5 \mathrm{Nm}^{3} \mathrm{Mg}^{-1}$ d.m.) and the lowest from Jerusalem artichoke (66 $\mathrm{Nm}^{3} \mathrm{Mg}^{-1}$ f.m.). Kowalczyk-Juśko et al. [38] found that Jerusalem artichoke treated by silage process had still some organic matter not degradable by fermentation. Methane production from $1 \mathrm{Mg}$ of dry matter $\left(187.09 \mathrm{Nm}^{3}\right)$ is almost twice lower compared with maize silage $\left(363.41 \mathrm{Nm}^{3}\right)$. The extrusion-cooking processing of Jerusalem artichoke biomass can be very efficient 
and can double the methane production. The increase in methane production efficiency from extruded Jerusalem artichoke only by $50 \%$ (up to $95.1 \mathrm{Nm}^{3} \mathrm{Mg}^{-1}$ ) made this substrate also interesting for biogas plants which commonly, in Europe, use maize silage. Pilarski et al. [10] reported the amount of methane expressed for fresh matter increasing by $16.48 \%$ for maize silage and by as much as $35.30 \%$ for maize straw silage in comparison with non-extruded substrates. They also showed that for pretreated maize straw the cumulative methane yield increased by $26.79 \%$. This could be the result of partial hydrolysis of cellulose and hemicellulose to monosaccharides, such as glucose, xylose, mannose, and galactose, which are easily and effectively decomposed, thus providing considerable amounts of methane [10].
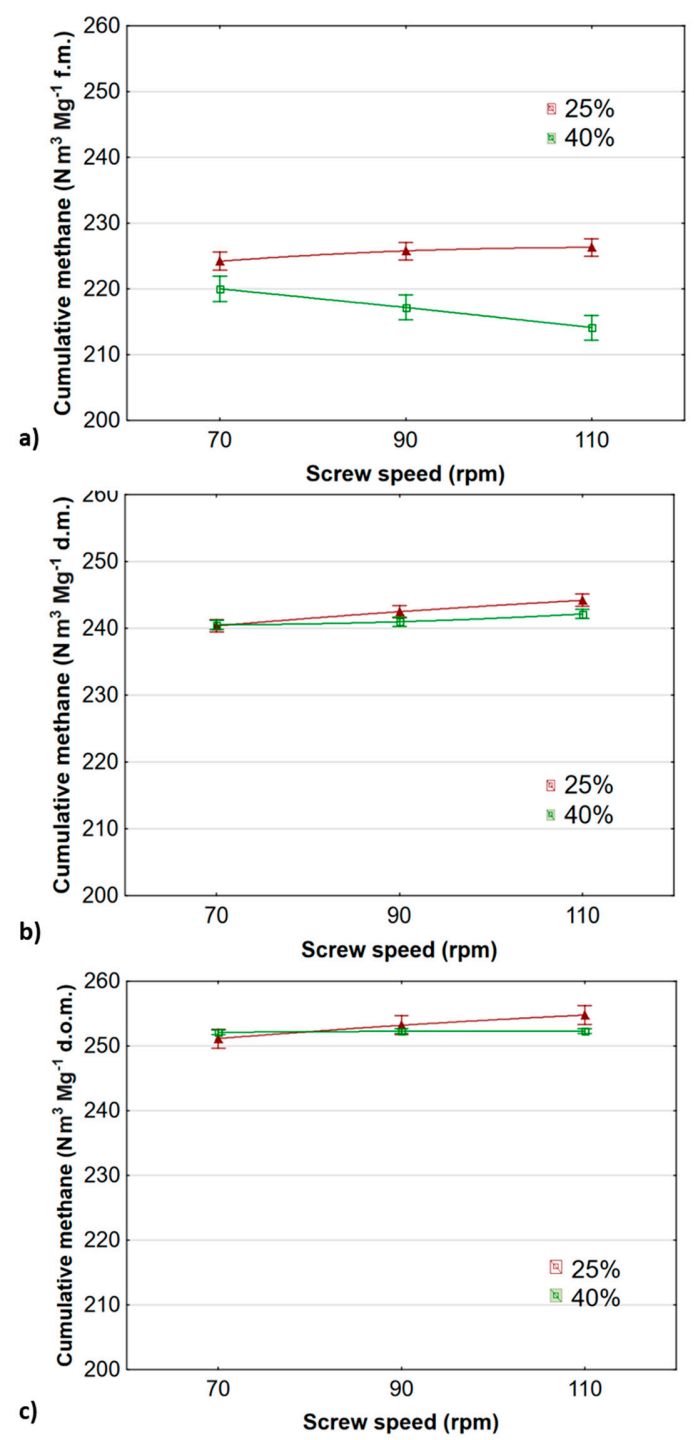

Figure 4. Cumulative methane efficiency from corn straw subjected to extrusion treatment at various screw speed and moisture content: (a) cumulative methane for fresh mass, (b) cumulative methane for dry matter, (c) cumulative methane for dry organic matter.

The content of cumulative biogas in all tested samples was higher than in the control straw, and the formation of accumulated biogas was more intensive, both for the dry and fresh substance (Figure 5). The amount of cumulative biogas during fermentation of untreated corn straw was $398.13 \mathrm{Nm}^{3} \mathrm{Mg}^{-1}$ for fresh matter, $442.58 \mathrm{Nm}^{3} \mathrm{Mg}^{-1}$ for dry matter, and $461.56 \mathrm{Nm}^{3} \mathrm{Mg}^{-1}$ for dry organic matter. Extrusion-cooking pretreatment of corn straw let to increase the efficiency of biogas production during fermentation with the growth by $9-10 \%$ from substrate fresh matter, $5-7 \%$ for dry matter, and $6-7 \%$ for dry organic matter, respectively, when $25 \%$ of moisture content was used compared to untreated corn 
straw. For fermentation of corn straw samples pretreated at $40 \%$ of moisture content, the increase in cumulative biogas efficiency was similar. Only for samples processed at $110 \mathrm{rpm}$, it reached $14 \%$ if calculated as dry matter. The highest values of cumulative biogas were obtained for organic dry matter at both moisture levels of corn straw applied during processing. The lowest efficiency cumulative biogas ( $425.84 \mathrm{Nm}^{3} \mathrm{Mg}^{-1}$ ) was observed in samples processed at $110 \mathrm{rpm}$ and $40 \%$ of initial moisture as expressed for fresh matter (Figure 5a). The highest efficiency accumulated biogas (501.98 $\mathrm{Nm}^{3} \mathrm{Mg}^{-1}$ ) was recorded for dry organic matter samples processed at $110 \mathrm{rpm}$ and at a higher moisture level of corn straw during processing (Figure 5c). Only in the case of application of $40 \%$ of initial moisture content of corn straw during processing, a slight decrease in efficiency of biogas was observed when calculated for fresh matter (Figure 5a). A significant effect $(p<0.05)$ of screw speed on cumulative biogas efficiency was observed for almost all variables, both in F-test and KW tests (Table 1). In almost all cases, high values of correlation coefficients suggest a positive effect on biogas efficiency of increased screw speed during the extrusion-cooking of corn straw. Only for cumulative methane and biogas, the effect was opposite when the initial moisture content was 40\%. Kowalczyk-Juśko et al. [38] proved that biogas efficiency with maize could be at the range of $684.70 \mathrm{Nm}^{3} \mathrm{Mg}^{-1}$ d.m., i.e., much higher than biogas production from Jerusalem artichoke: $375.30 \mathrm{Nm}^{3} \mathrm{Mg}^{-1} \mathrm{~d} . \mathrm{m}$.
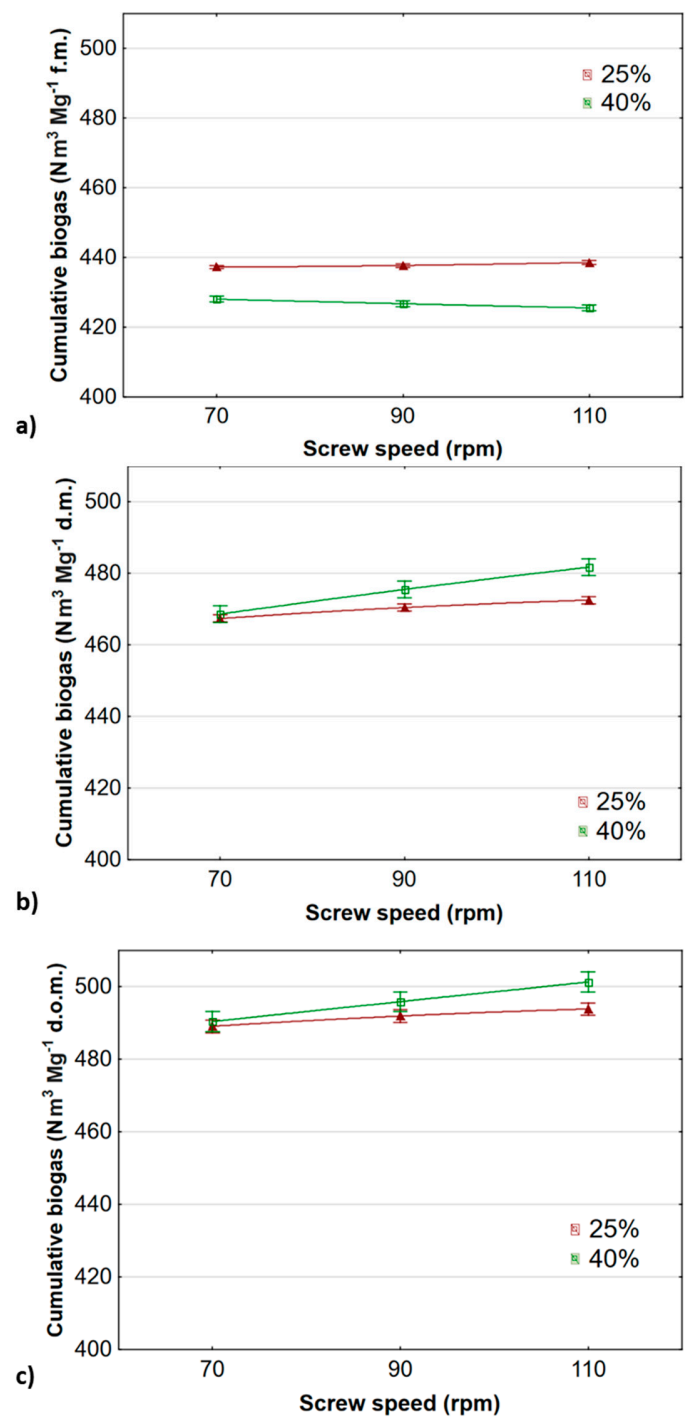

Figure 5. Cumulative biogas efficiency with corn straw subjected to extrusion treatment at various screw speeds and moisture content: (a) cumulative biogas for fresh mass, (b) cumulative biogas for dry matter, (c) cumulative biogas for dry organic matter. 
Maize straw extrusion studies were also conducted by other authors. Kozłowski et al. [39] conducted research on the energy potential of the untreated maize straw and extruded maize straw used in biogas production. Cumulated biogas for untreated maize straw was $407.81 \mathrm{Nm}^{3} \mathrm{Mg}^{-1}$ and $438.40 \mathrm{Nm}^{3} \mathrm{Mg}^{-1}$ for extruded maize straw (fresh mass) and methane production respectively by 7.50 and $8.51 \%$. Amith Abraham et al. [40] using the extrusion process obtained a 33\% increase in biogas productivity and Dell'Omo 49.1\% [41].

\subsection{Analysis of Samples Using FTIR Infrared Spectroscopy}

FTIR infrared spectroscopy was employed to characterize selected samples at the molecular level in greater detail. For more convenient presentation, description, and interpretation of obtained results, all bands are shown in Figure 6 and Table 2 (for the spectral range of $3700-650 \mathrm{~cm}^{-1}$ ). For the samples of corn, corn straw at $25 \%$ of moisture content (at 70 and $110 \mathrm{rpm}$ ) and for corn straw at $40 \%$ of moisture content (at 70 and $110 \mathrm{rpm}$ ), as shown in Table, the vibrations of characteristic functional groups found in systems with more lignocellulose structures were assigned to the appropriate bands.

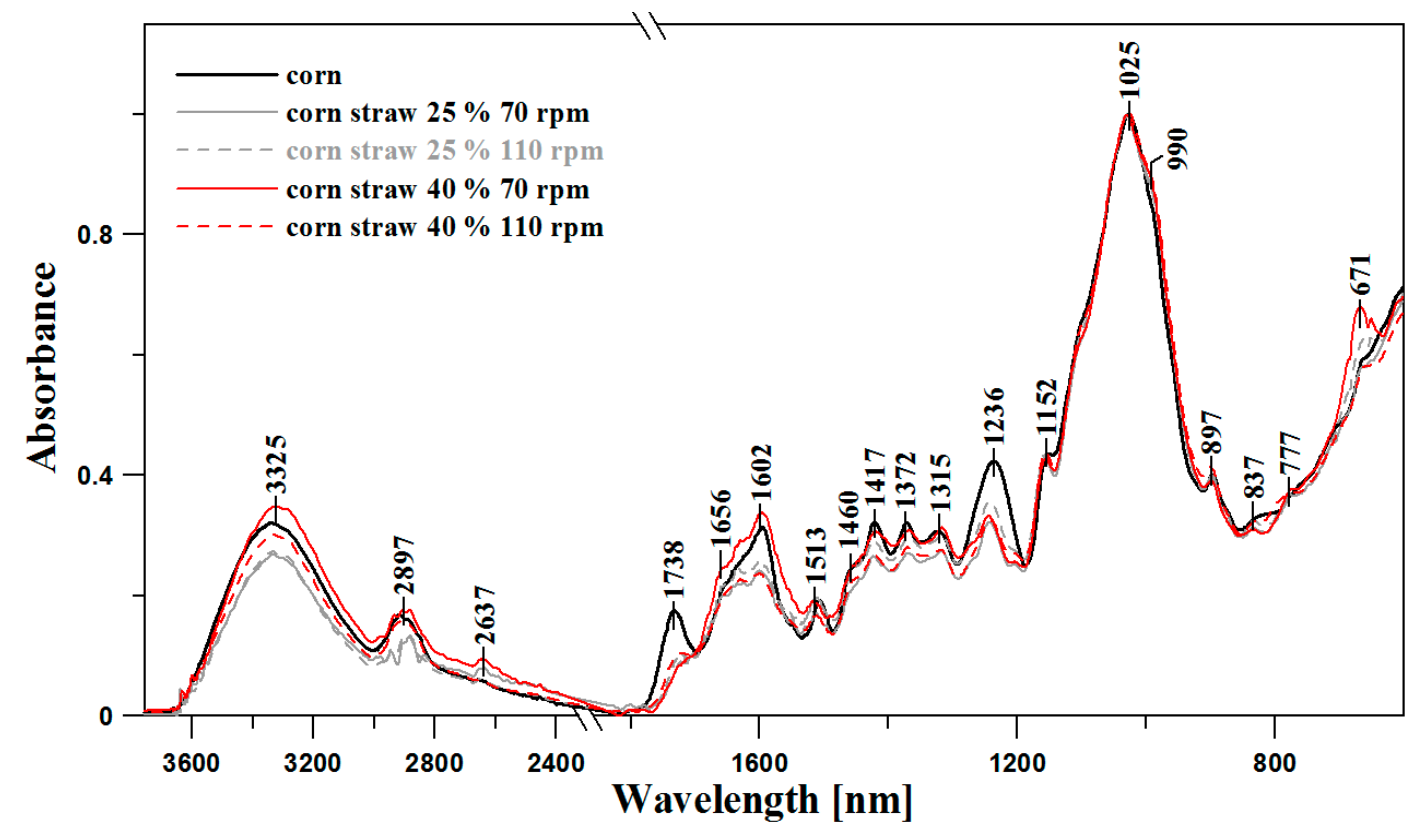

Figure 6. Normalized FTIR infrared spectra for samples of: corn, corn straw $25 \%$ and $70 \mathrm{rpm}, 25 \%$ and $110 \mathrm{rpm}$, and corn straw $40 \%$ and $70 \mathrm{rpm}$ and $40 \%$ and $110 \mathrm{rpm}$ for the spectra of $3750-600 \mathrm{~cm}^{-1}$.

As reported by Kondo [42], Liang et al. [43] or Hospodarova et al. [44], the first very characteristic vibration area in the tested samples, i.e., vibrations with a maximum at $\sim 3325 \mathrm{~cm}^{-1}$, concerns tensile vibrations of -OH groups present in the lignocellulose structure, which are the main component of the samples selected for testing (Table 2 and Figure 6). Evidently (as shown in Figure 6), the intensity of vibrations from this area is mainly amplified by a change in the humidity level in the tested samples. This band, as seen in the literature data, may exhibit noticeable shifts as the connections of the components for minginter molecular hydrogen bonds increases, which may take place in this case. Another particularly important area corresponds to the tensile vibrations of $\mathrm{C}-\mathrm{H}$ groups in $\mathrm{CH}_{2}$ and $\mathrm{CH}_{3}$ groups in the lignocellulose structure, the maximum of these vibrations is about $2897 \mathrm{~cm}^{-1}$, although the area is irregular, probably because of the used agents. These vibrations, mainly due to the variable rpm values, 70 and 110, (particularly evident in this case) differ significantly and are fairly irregular, which can indicate a higher level of degradation of samples selected for testing. Quite intensive and irregular absorption of the wide vibrations of the -OH groups described above upholds the much weaker tensile vibrations of the $\mathrm{C}-\mathrm{H}$ groups in the tested structures (see Figure 6). 
Table 2. The location of the maxima of FTIR absorption bands with the arrangement of appropriate vibration for selected samples of: corn, corn straw $25 \%$ and $70 \mathrm{rpm}, 25 \%$ and $110 \mathrm{rpm}$ and corn straw $40 \%$ and $70 \mathrm{rpm}$ and $40 \%$ and $110 \mathrm{rpm}$ for the spectra of $3750-600 \mathrm{~cm}^{-1}$.

\begin{tabular}{|c|c|c|c|c|c|}
\hline \multicolumn{5}{|c|}{ FTIR } & \multirow{3}{*}{ Type and Origin of Vibrations } \\
\hline \multicolumn{5}{|c|}{ Position of Bands $\left[\mathrm{cm}^{-1}\right]$} & \\
\hline Corn & $\begin{array}{l}\text { Corn Straw } \\
25 \% 70 \mathrm{rpm}\end{array}$ & $\begin{array}{l}\text { Corn Straw } \\
25 \% 110 \mathrm{rpm}\end{array}$ & $\begin{array}{l}\text { Corn Straw } \\
40 \% 70 \mathrm{rpm}\end{array}$ & $\begin{array}{l}\text { Corn Straw } \\
40 \% 110 \mathrm{rpm}\end{array}$ & \\
\hline 3332 & 3332 & 3336 & 3320 & 3324 & $\begin{array}{c}v(\mathrm{O}-\mathrm{H}) \text { in } \mathrm{H}_{2} \mathrm{O} \\
\text { And intra-molecular hydrogen } \\
\text { bonding }\end{array}$ \\
\hline 2912 & 2936 & 2944 & 2924 & 2912 & \multirow{2}{*}{$\begin{array}{c}v(\mathrm{C}-\mathrm{H}) \text { in } \mathrm{CH}_{2} \text { and } \mathrm{CH}_{3} \text { asymetrical } \\
\text { and symmetrical }\end{array}$} \\
\hline 2876 & 2892 & 2892 & 2888 & 2884 & \\
\hline 1731 & 1727 & 1725 & 1724 & 1731 & $v(\mathrm{C}=\mathrm{O})$ \\
\hline 1656 & 1663 & 1661 & 1660 & 1665 & $v(\mathrm{C}=\mathrm{C})$ and $\delta(\mathrm{O}-\mathrm{H})$ \\
\hline- & 1635 & 1639 & 1626 & 1633 & $\delta(\mathrm{O}-\mathrm{H})$ adsorbed $\mathrm{H}_{2} \mathrm{O}$ \\
\hline 1599 & 1597 & 1599 & 1597 & 1603 & \multirow{2}{*}{$v(\mathrm{C}=\mathrm{C})$} \\
\hline 1509 & 1511 & 1516 & 1513 & 1513 & \\
\hline 1460 & 1460 & 1462 & 1458 & 1460 & $\delta(-\mathrm{OH}$ in plane), \\
\hline 1424 & 1422 & 1422 & 1426 & 1426 & $\delta\left(\mathrm{CH}_{2}\right)$ \\
\hline 1373 & 1375 & 1368 & 1371 & 1371 & $\delta(\mathrm{C}-\mathrm{H})$ \\
\hline 1322 & 1319 & 1320 & 1317 & 1320 & $\delta(\mathrm{C}-\mathrm{H})$ and $\delta(\mathrm{O}-\mathrm{H})$ \\
\hline 1236 & 1239 & 1241 & 1249 & 1239 & $\begin{array}{c}\delta(\mathrm{C}-\mathrm{H}) \text { and antisymmetrical bridge } \\
\text { oxygen stretching -OH in-plane } \\
\text { bending }\end{array}$ \\
\hline 1158 & 1156 & 1156 & 1160 & 1158 & \multirow{3}{*}{$\begin{array}{c}\text { antisymmetrical in phase ring } \\
\text { stretching } \\
\text { and } v(\mathrm{C}-\mathrm{O})\end{array}$} \\
\hline 1096 & 1098 & 1100 & 1106 & 1096 & \\
\hline 1028 & 1025 & 1026 & 1028 & 1030 & \\
\hline 987 & 994 & 994 & 989 & 989 & $v(\mathrm{C}-\mathrm{O})$ \\
\hline 896 & 895 & 896 & 895 & 898 & \multirow{6}{*}{$\begin{array}{c}\mathrm{CH}_{2} \text { rocking } \\
\beta \text {-linkage of cellulose } \\
\text { ring breathing } \\
\text { and antisymmetrical out of phase } \\
\text { stretching } \\
\text {-OH out-of-plane bending }\end{array}$} \\
\hline 827 & 832 & 834 & 834 & 836 & \\
\hline 778 & 782 & 774 & 774 & 778 & \\
\hline 702 & - & - & - & - & \\
\hline 663 & 659 & 663 & 669 & 659 & \\
\hline & & & & & \\
\hline
\end{tabular}

$v$ —stretching vibrations, $\delta$-deformation vibrations

It is worth stressing that the usually very broad vibration bands $v(-\mathrm{OH})$ are the result of formation of strong hydrogen bonds belonging to the interactions between structural units in the main component of the tested samples, i.e., lignocellulose [42]. The deformation vibrations of -OH groups, on the other hand, correspond to the band with the maximum of $\sim 1656 \mathrm{~cm}^{-1}[43,45]$. In the case of the tested samples, this band may also come from tensile vibrations $C=C$ [46]. Another very important vibration area concerns bands with a maximum of about $1738 \mathrm{~cm}^{-1}$ corresponding to the tensile vibrations of the carbonyl group (Figure 6). This area (occurring mainly as a reinforcement of the band with a maximum of about $1656 \mathrm{~cm}^{-1}$ ) differs significantly in intensity depending on the moisture content in the sample as well as screw speed during its processing. A noticeable change in the vibration intensity for this band can be a clear indication of degradation processes occurring in the tested samples.

Moving on to the fingerprint region $\left(\sim 1500\right.$ and $\left.700 \mathrm{~cm}^{-1}\right)$, the presented spectra reveal rich bands that are significant for interpretation reasons. The following vibrations need to be mentioned: deformation vibrations of the C-H group $\left(1370 \mathrm{~cm}^{-1}\right)$ [47], deformation vibrations of $\mathrm{CH}_{2}\left(1426 \mathrm{~cm}^{-1}\right)$, and deformation vibrations of the -OH groups visible in the chemical structure of the main compound of the tested samples, i.e., lignocellulose $[46,48]$. Highly reliable are also vibrations with the maximum 
of $\sim 1152 \mathrm{~cm}^{-1}$ originating in the tensile vibrations of the ring as well as in the tensile vibrations of the C-O groups. On the other hand, vibrations with the maximum at $\sim 1025$ and $\sim 989 \mathrm{~cm}^{-1}$ mainly come from the tensile vibrations of the $\mathrm{C}-\mathrm{O}$ groups. It should be noted that, despite the agents involved, these bands do not differ much compared with the spectrum of the control sample (maize) in this spectral range. These bands owe their intensity mainly to the tensile vibrations in the C-O-C group of the lignocellulose structure. At the end of the description and discussion of the obtained FTIR vibrations, small but noticeable differences should also be highlighted in the shape of the bands in the range from 900 to $650 \mathrm{~cm}^{-1}$. These are the vibrations in sugar fraction bonds forming the lignocellulose structure. These vibrations reveal the greatest changes in the area of $\sim 671 \mathrm{~cm}^{-1}$, i.e., in the area with extra deformation vibrations of -OH groups which can be part of the formation of hydrogen bonds between individual lignocellulose units. To sum up, it should be noted that the performed FTIR spectroscopy studies offer an extensive interpretative perspective for further studies of this type of materials to be carried out in subsequent stages. The bands that are the most reliable in terms of assessment of degradation changes occurring in the analyzed samples are the vibrations described in detail above, i.e., $3325,2897,1738,1236,837$, and $671 \mathrm{~cm}^{-1}$.

\section{Conclusions}

Pretreated corn straw moistened to $25 \%$ of initial moisture content and processed at the highest rpm during the extrusion-cooking process proved to provide the most efficient conditions for methane and biogas production efficiency. Both in the case of dry matter and dry organic matter, the rotational speed of the extruder screw had an impact on the production of biogas and methane. With a higher rotational speed of the extruder screw, the production of cumulated biogas and methane increased. These conditions showed to have the least energy demand during pretreatment, so they can be recommended as a pretreatment method useful for increasing biogas efficiency at low energy expenditure. Pretreatment of corn straw by extrusion-cooking increased the amount of methane accumulated in the fresh biomass matter as well as accumulated biogas compared to unprocessed samples. The amount of methane and biogas accumulated from extruded organic dry matter grew compared to the untreated biomass of corn. Because of low cost and availability (post-consumer waste), corn straw is the ideal raw material for use in agricultural biogas plants. Because of the difficult degradation properties of this material, it must be pre-processed. Pretreatment of corn straw showed a positive effect on the acquisition of biogas and methane. Our studies demonstrate that the energy used for pretreatment is significantly lower compared to the increase in energy associated with the increase in methane efficiency. Residues obtained after the fermentation process can be used as a fertilizer, meaning that no post-production waste is generated, and the raw material is fully used. In the FTIR studies, bands were clearly detected which indicate the influence of the applied agents on the processes, which indicates that the selection of appropriate agents may significantly accelerate the degradation of the main lignocellulose structures during the degradation processes. Further research should be based on finding optimal parameters of pretreatment of other cereal straw or energy plants that allow obtaining highest (51.63\% for pre-treated straw) efficiency biogas and methane while maintaining low energy requirements.

Author Contributions: Conceptualization, T.O., M.C., and W.C.; data curation, K.K., T.O., M.C., W.C., and A.M.; formal analysis, K.K., T.O., M.C., W.C., and A.M.; Investigation, K.K., T.O., M.C., W.C., and A.M.; methodology, K.K., T.O., M.C., W.C., and A.M.; project administration, T.O., M.C., and W.C.; resources, K.K., T.O., M.C., and W.C.; software, K.K., M.C., and A.M.; supervision, T.O. and M.C.; validation, K.K., T.O., W.C., and A.M.; visualization, T.O., M.C., and W.C.; writing—original draft, K.K., T.O., M.C., W.C., and A.M. All authors have read and agreed to the published version of the manuscript.

Funding: This research was funded from the "Excellent science" program of the Ministry of Science and Higher Education as a part of the contract no. DNK/SP/465641/2020 "The role of the agricultural engineering and environmental engineering in the sustainable agriculture development".

Conflicts of Interest: The authors have no competing interests to declare. 


$\begin{array}{ll}\text { Abbreviations } & \\ \text { List of symbols and abbreviations: } \\ \text { rpm } & \text { rotations per minute } \\ \mathrm{Nm}^{3} \mathrm{Mg}^{-1} & \text { normal cubic meter per megagram } \\ \text { FTIR } & \text { Fourier transform Infrared spectroscopy } \\ \mathrm{NaWaRo} & \text { NachWachsendeRohstoffe } \\ \text { L/D } & \text { length/diameter } \\ \text { SME } & \text { specific mechanical energy }\left(\mathrm{kWh} \mathrm{kg}^{-1}\right) \\ \mathrm{n} & \text { screw rotation }(\mathrm{rpm}) \\ \mathrm{nm} & \text { screw rating rotation }(\mathrm{rpm}) \\ \mathrm{O} & \text { engine load compared to maximum }(\%) \\ \mathrm{P} & \text { rated power }(\mathrm{kW}) \\ \mathrm{Q} & \text { process efficiency }\left(\mathrm{kg} \mathrm{h} \mathrm{h}^{-1}\right) \\ \text { WAI } & \text { water absorption index }\left(\mathrm{g} \mathrm{g}^{-1}\right) \\ \text { WSI } & \text { water solubility index }(\%) \\ \text { ATR } & \text { Attenuated Total Reflection } \\ \text { SD } & \text { standard deviation } \\ \text { f.m. } & \text { fresh matter } \\ \text { d.m. } & \text { dry matter } \\ \text { d.o.m. } & \text { dry organic matter } \\ \text { ATR } & \text { Attenuated Total Reflection }\end{array}$

\section{References}

1. Bruni, E.; Jensen, A.P.; Angelidaki, I. Comparative study of mechanical, hydrothermal, chemical and enzymatic treatments of digested biofibers to improve biogas production. Bioresour. Technol. 2010, 101, 8713-8717. [CrossRef] [PubMed]

2. Waliszewska, H.; Zborowska, M.; Waliszewska, B.; Borysiak, S.; Antczak, A.; Czekała, W. Transformation of Miscanthus and Sorghum cellulose during methane fermentation. Cellulose 2018, 25, 1207-1216. [CrossRef]

3. Waliszewska, H.; Zborowska, M.; Stachowiak-Wencek, A.; Waliszewska, B.; Czekała, W. Lignin Transformation of One-Year-Old Plants during Anaerobic Digestion (AD). Polymers 2019, 11, 835. [CrossRef] [PubMed]

4. Obidziński, S.; Joka, M.; Fijoł, O. Two-stage agglomeration of fine-grained herbal nettle waste. Int. Agrophys. 2017, 31, 515-523. [CrossRef]

5. Oniszczuk, T.; Kupryaniuk, K.; Smurzyńska, A.; Brzoski, M.; Wójtowicz, A.; Mitrus, M.; Oniszczuk, A.; Combrzyński, M.; Do Carmo, I.E.P. Effect of extrusion-cooking parameters on energetic efficiency of corn straw during methane fermentation. In Proceedings of the 3rd International Conference on Energy and Environment, Porto, Portugal, 29-30 June 2017; Available online: https://www.fep.up.pt/conferences/icee2017/ images/ICEE2017_0808_VF.pdf (accessed on 30 June 2017).

6. Zheng, Y.; Zhao, J.; Xu, F.; Li, Y. Pretreatment of lignocellulosic biomass for enhanced biogas production. Prog. Energy Combust. Sci. 2014, 42, 35-53. [CrossRef]

7. Eastman, J.A.; Ferguson, J.F. Solubilization of particulate organic carbon during the acid phase of anaerobic digestion. J. Water Pollut. Control Fed. 1981, 53, 352-366.

8. Di Matteo, U.; Nastasi, B.; Albo, A.; Garcia, D.A. Energy Contribution of OFMSW (Organic Fraction of Municipal Solid Waste) to Energy-Environmental Sustainability in Urban Areas at Small Scale. Energies 2017, 10, 229. [CrossRef]

9. Tong, X.; Smith, L.H.; Mccarty, P.L. Methane fermentation of selected lignocellulosic materials. Biomass 1990, 21, 239-255. [CrossRef]

10. Pilarski, K.; Pilarska, A.A.; Witaszek, K.; Dworecki, Z.; Żelaziński, T.; Ekielski, A.; Makowska, A.; Michniewicz, J. The impact of extrusion on the biogas and biomethane yield of plant substrates. J. Ecol. Eng. 2016, 17, 264-272. [CrossRef]

11. Chandra, R.; Takeuchi, H.; Hasegawa, T. Hydrothermal pretreatment of rice straw biomass: A potential and promising method for enhanced methane production. Appl. Energy 2012, 94, 129-140. [CrossRef] 
12. Song, Z.; Yang, G.; Han, X.; Feng, Y.; Ren, G. Optimization of the Alkaline Pretreatment of Rice Straw for Enhanced Methane Yield. BioMed Res. Int. 2012, 2013, 1-9. [CrossRef]

13. Zhu, S.; Wu, Y.; Yu, Z.; Liao, J.; Zhang, Y. Pretreatment by microwave/alkali of rice straw and its enzymic hydrolysis. Process. Biochem. 2005, 40, 3082-3086. [CrossRef]

14. Hjorth, M.; Gränitz, K.; Adamsen, A.P.; Møller, H. Extrusion as a pretreatment to increase biogas production. Bioresour. Technol. 2011, 102, 4989-4994. [CrossRef] [PubMed]

15. Wójtowicz, A.; Mitrus, M.; Oniszczuk, T.; Moscicki, L.; Kręcisz, M.; Oniszczuk, A. Selected Physical Properties, Texture and Sensory Characteristics of Extruded Breakfast Cereals based on Wholegrain Wheat Flour. Agric. Agric. Sci. Procedia 2015, 7, 301-308. [CrossRef]

16. Wójtowicz, A.; Oniszczuk, A.; Oniszczuk, T.; Kocira, S.; Wojtunik-Kulesza, K.A.; Mitrus, M.; Kocira, A.; Widelski, J.; Skalicka-Woźniak, K. Application of Moldavian dragonhead (Dracocephalum moldavica L.) leaves addition as a functional component of nutritionally valuable corn snacks. J. Food Sci. Technol. 2017, 54, 3218-3229. [CrossRef] [PubMed]

17. Pilarska, A.; Pilarski, K.; Dach, J.; Boniecki, P. Wpływ rozwoju biogazowni na dywersyfikację dochodów w rolnictwie. Tech. Rol. Ogrod. Leśna 2014, 1, 10-12. Available online: http://yadda.icm.edu.pl/yadda/element/ bwmeta1.element.agro-8f7f2fe7-ff9a-45a5-8491-64e320e5b0eb/c/PPB1_2014.pdf (accessed on 1 January 2014).

18. Oniszczuk, T.; Pilawka, R. Effect of cellulose fibers on thermal strength of thermoplastic starch. Przem. Chem. 2013, 92, 265-269.

19. Oniszczuk, T. Addition of bark in the production of the starch-based composites Dodatek kory w produkcji biokompozytów skrobiowych. Przem. Chem. 2015, 1, 122-125. [CrossRef]

20. Oniszczuk, T.; Wójtowicz, A.; Mościcki, L.; Mitrus, M.; Kupryaniuk, K.; Kusz, A.; Bartnik, G. Effect of natural fibres on the mechanical properties of thermoplastic starch. Int. Agrophys. 2016, 30, 211-218. [CrossRef]

21. Czekała, W. Agricultural Biogas Plants as a Chance for the Development of the Agri-Food Sector. J. Ecol. Eng. 2018, 19, 179-183. [CrossRef]

22. Weiland, P. Biogas production: Current state and perspectives. Appl. Microbiol. Biotechnol. 2009, 85, 849-860. [CrossRef] [PubMed]

23. Raven, R.; Gregersen, K. Biogas plants in Denmark: Successes and setbacks. Renew. Sustain. Energy Rev. 2007, 11, 116-132. [CrossRef]

24. Lantz, M.; Svensson, M.; Björnsson, L.; Börjesson, P. The prospects for an expansion of biogas systems in Sweden-Incentives, barriers and potentials. Energy Policy 2007, 35, 1830-1843. [CrossRef]

25. Rasi, S.; Veijanen, A.; Rintala, J. Trace compounds of biogas from different biogas production plants. Energy 2007, 32, 1375-1380. [CrossRef]

26. Wojcieszak, D.; Przybył, J.; Ratajczak, I.; Goliński, P.; Janczak, D.; Waśkiewicz, A.; Szentner, K.; Woźniak, M. Chemical composition of maize stover fraction versus methane yield and energy value in fermentation process. Energy 2020, 198, 117258. [CrossRef]

27. Sousa, G.O.C.; Rodrigues, R.C.; Lima, J.R.L.; Lima, N.M.; Miranda, B.E.C.; Jesus, A.P.R.; Parente, H.N.; Costa, C.D.S. Nutritional value of dehydrated maize straw ammoniated with urea. Rev. Bras. Saúde Prod. Anim. 2019, 20, 0132019. [CrossRef]

28. Combrzyński, M.; Matwijczuk, A.; Wójtowicz, A.; Oniszczuk, T.; Karcz, D.; Szponar, J.; Niemczynowicz, A.; Bober, D.; Mitrus, M.; Kupryaniuk, K.; et al. Potato Starch Utilization in Ecological Loose-Fill Packaging Materials-Sustainability and Characterization. Materials 2020, 13, 1390. [CrossRef]

29. Bouasla, A.; Wójtowicz, A.; Zidoune, M.N. Gluten-free precooked rice pasta enriched with legumes flours: Physical properties, texture, sensory attributes and microstructure. LWT 2017, 75, 569-577. [CrossRef]

30. Dach, J.; Czekała, W.; Boniecki, P.; Lewicki, A.; Piechota, T. Specialised Internet Tool for Biogas Plant Modelling and Marked Analysing. Adv. Mater. Res. 2014, 909, 305-310. [CrossRef]

31. Czekała, W. Concept of in-oil project based on bioconversion of by-products from food processing industry. J. Ecol. Eng. 2017, 18, 180-185. [CrossRef]

32. Chocyk, D.; Gładyszewska, B.; Ciupak, A.; Oniszczuk, T.; Mościcki, L.; Rejak, A. Influence of water addition on mechanical properties of thermoplastic starch foils. Int. Agrophys. 2015, 29, 267-273. [CrossRef]

33. Menardo, S.; Cacciatore, V.; Balsari, P. Batch and continuous biogas production arising from feed varying in rice straw volumes following pre-treatment with extrusion. Bioresour. Technol. 2015, 180, 154-161. [CrossRef] [PubMed] 
34. Mitrus, M.; Combrzyński, M.; Kupryaniuk, K.; Oniszczuk, T.; Kręcisz, M.; Matysiak, A.; Smurzyńska, A.; Mościcki, L.; Wójtowicz, A. A study of the solubility of biodegradable foams of thermoplastic starch. J. Ecol. Eng. 2016, 17, 184-189. [CrossRef]

35. Wolna-Maruwka, A.; Pilarski, K. Microbiological characteristic of compost prepared on the basis of sewage sludge supplemented with refined glycerol. Arch. Environ. Prot. 2011, 37, 43-45.

36. Czekała, W.; Smurzyńska, A.; Cieślik, M.; Boniecki, P.; Kozłowski, K. Biogas efficiency of selected fresh fruit covered by the Russian embargo. Energy Clean Technol. Conf. Proc. 2016, 3, 227-233. [CrossRef]

37. Gizińska-Górna, M.; Czekała, W.; Jóźwiakowski, K.; Lewicki, A.; Dach, J.; Marzec, M.; Pytka, A.; Janczak, D.; Kowalczyk-Juśko, A.; Listosz, A. The possibility of using plants from hybrid constructed wetland wastewater treatment plant for energy purposes. Ecol. Eng. 2016, 95, 534-541. [CrossRef]

38. Kowalczyk-Juśko, A.; Kupryaniuk, K.; Oniszczuk, T.; Wójtowicz, A.; Janczak, D.; Smurzyńska, A.; Jóźwiakowski, K.; Czechlowski, M. Applicability of Jerusalem artichoke in agricultural biogas plants as maize silage alternative. In Proceedings of the 3rd International Conference on Energy and Environment, Porto, Portugal, 29-30 June 2017; Available online: https://www.fep.up.pt/conferences/icee2017/images/ ICEE2017_0808_VF.pdf (accessed on 30 June 2017).

39. Kozłowski, K.; Lewicki, A.; Czekała, W.; Wójtowicz, A.; Kupryaniuk, K.; Dróżd, D. Extrusion pretreatment of maize straw-Case study for a Polish biogas plants. Int. Agrophys. 2019, 33, 527-535. [CrossRef]

40. Abraham, A.; Mathew, A.K.; Park, H.; Choi, O.; Sindhu, R.; Parameswaran, B.; Pandey, A.; Park, J.H.; Sang, B.-I. Pretreatment strategies for enhanced biogas production from lignocellulosic biomass. Bioresour. Technol. 2020, 301, 122725. [CrossRef]

41. Dell'Omo, P.P.; Spena, V.A. Mechanical pretreatment of lignocellulosic biomass to improve biogas production: Comparison of results for giant reed and wheat straw. Energy 2020, 203, 117798. [CrossRef]

42. Kondo, T. The assignment of IR absorption bands due to free hydroxyl groups in cellulose. Cellulose 1997, 4, 281-292. [CrossRef]

43. Liang, C.Y.; Marchessault, R.H. Infrared spectra of crystalline polysaccharides. II. Native celluloses in the region from 640 to $1700 \mathrm{~cm} .1$. J. Polym. Sci. 1959, 39, 269-278. [CrossRef]

44. Hospodarova, V.; Singovszka, E.; Stevulova, N. Characterization of Cellulosic Fibers by FTIR Spectroscopy for Their Further Implementation to Building Materials. Am. J. Anal. Chem. 2018, 9, 303-310. [CrossRef]

45. Driemeier, C.; Mendes, F.M.; Ling, L.Y. Hydrated fractions of cellulosics probed by infrared spectroscopy coupled with dynamics of deuterium exchange. Carbohydr. Polym. 2015, 127, 152-159. [CrossRef] [PubMed]

46. Das, A.M.; Ali, A.A.; Hazarika, M.P. Synthesis and characterization of cellulose acetate from rice husk: Eco-friendly condition. Carbohydr. Polym. 2014, 112, 342-349. [CrossRef]

47. De Dicastillo, C.L.; Rodríguez, F.; Guarda, A.; Galotto, M.J. Antioxidant films based on cross-linked methyl cellulose and native Chilean berry for food packaging applications. Carbohydr. Polym. 2016, 136, 1052-1060. [CrossRef]

48. Abidi, N.; Cabrales, L.; Haigler, C.H. Changes in the cell wall and cellulose content of developing cotton fibers investigated by FTIR spectroscopy. Carbohydr. Polym. 2014, 100, 9-16. [CrossRef]

(C) 2020 by the authors. Licensee MDPI, Basel, Switzerland. This article is an open access article distributed under the terms and conditions of the Creative Commons Attribution (CC BY) license (http://creativecommons.org/licenses/by/4.0/). 